Northwestern University School of Law

Northwestern University School of Law Scholarly Commons

Faculty Working Papers

2010

\title{
Careful With That Gun: Lee, George, Wax, and Geach on Gay Rights and Same-Sex Marriage
}

Andrew Koppelman

Northwestern University School of Law, akoppelman@law.northwestern.edu

\section{Repository Citation}

Koppelman, Andrew, "Careful With That Gun: Lee, George, Wax, and Geach on Gay Rights and Same-Sex Marriage" (2010). Faculty Working Papers. Paper 30.

http://scholarlycommons.law.northwestern.edu/facultyworkingpapers/30

This Working Paper is brought to you for free and open access by Northwestern University School of Law Scholarly Commons. It has been accepted for inclusion in Faculty Working Papers by an authorized administrator of Northwestern University School of Law Scholarly Commons. 
Draft: Jan. 11, 2010

\author{
Careful With That Gun: \\ Lee, George, Wax, and Geach on \\ Gay Rights and Same-Sex Marriage
}

Andrew Koppelman*

About half of Americans think that homosexual sex is morally wrong. ${ }^{1}$ More than half oppose same-sex marriage. ${ }^{2}$

* John Paul Stevens Professor of Law and Professor of Political Science, Northwestern University. Thanks to Marcia Lehr and Michelle Shaw for research assistance, and to June Carbone, Mary Anne Case, Mary Geach, Martha Nussbaum, and Dorothy Roberts for helpful comments. 1 This number is however shrinking. The Gallup poll found in 1982 that only 34 percent of respondents agreed that "homosexuality should be considered an acceptable alternative lifestyle." The number increased to 50 percent in 1999 and 57 percent in 2007. Lydia Saad, Americans Evenly Divided on Morality of Homosexuality, June 18, 2008, available at http://www.gallup.com/poll/108115/Americans-Evenly-Divided-MoralityHomosexuality.aspx (visited April 27, 2009). In 2001, 53응 Af Americans thought that homosexual relations were morally wrong, while $40 \%$ considered them morally acceptable; in 2008, the split was 48 to 48 . Id.

2 According to Gallup, 57\% oppose same-sex marriage. Jeffrey M. Jones, Majority of Americans Continue to Oppose Gay Marriage, May 27, 2009, available at http://www.gallup.com/poll/118378/Majority-AmericansContinue-Oppose-Gay-Marriage.aspx (visited Oct. 14, 2009). But there is a sharp generational divide: among those 18 to 34 years old, 58 percent supported same-sex marriages. That number drops to 42 percent among respondents aged 35 to 49 , to 41 percent of those aged 50 to 64, and only 24 percent of Americans 65 and older. Paul Steinhauser, CNN Poll: Generations Disagree on Same-Sex Marriage, May 4, 2009, available at http://www.cnn.com/2009/US/05/04/samesex.marriage.poll/ (visited July 2, 2009). Other polls reach similar results. Arian Campo-Flores, A Gay Marriage Surge, Newsweek, Dec. 5, 2008, available at http://www.newsweek.com/id/172399 (visited July 2, 2009); Adam Nagourney, On Politics: Signs G.O.P. Is Rethinking Stance on Gay Marriage, Apr. 28, 2008. The effect is even noticeable among white evangelical Christians, otherwise a very conservative lot: 58 percent of those 18-29 years old support some legal recognition of same-sex couples, with 26 percent supporting marriage rights. Only 46 percent of those over 30 support any legal recognition, with 9 percent supporting marriage. Greenberg Quinlan Rosner Research, Inc., Young Evangelical Christians and the 2008 Election, Sept. 292008 , available at http://www.greenbergresearch.com/index.php?ID=2251 (visited Oct. 22, 2009). Older evangelicals also care much more about the issue: according to a Pew Forum study, 61.8 percent of those over 60 said that "stopping gay marriage" was very important, while only 34 percent of 
Philosophers trying to defend these views have relied on two strategies. One is to claim that such sex is wrong irrespective of consequences: there is something intrinsic to sex that makes it only licit when it takes place within a heterosexual marriage (in which there is no contraception or possibility of divorce). This argument's weakness is that it moves so quickly from premise to conclusion: unless you perceive marriage, as defined in this peculiar way, to be intrinsically good, the argument can't even get started. The second strategy focuses on consequences: the baleful effects on heterosexual families of societal tolerance for homosexuality. This argument has foundered for lack of evidence. ${ }^{3}$

This article is a critique of recent attempts to reinvigorate these strategies. Patrick Lee and Robert P. George have offered clarifications of the first strategy in order to rebut objections from many scholars. Amy Wax (who is not a clear opponent of same-sex marriage, but who is worried by it) has tried to array evidence to support the second. Mary Geach has developed a novel hybrid, relying on the second argument to support the first one.

The coherence problems of the first view remain. Its deepest difficulty lies in its need to show that the intrinsic goodness of sex is at once (a) derived from its reproductive character and (b) present in the coitus of married couples who know themselves to be infertile, but not present in any sex act other than heterosexual marital coitus.

As for evidence of bad consequences of tolerance of homosexuality, the evidence is all the other way. The sexual ethic all these authors revere is indeed decaying. That is why they are alarmed. But it is its remnants that are doing the most damage in contemporary society. The growing tolerance of homosexuality is part of a larger shift in sexual ethics that separates sex from reproduction. The effects have been good for some groups in American society and bad for others. The good effects are concentrated among those who have most deeply absorbed the new ethic. Within that population, children are thriving, and they are thriving because their parents used

those 29 and under said so. Steven Waldman, Abortion vs.

Homosexuality: The Evangelical Age Gap,

http://blog.beliefnet.com/stevenwaldman/2008/07/abortion-vshomosexuality-the.html (visited Oct. 22, 2009) (also citing similar data from Barna Research).

3 I have previously examined both claims in the Decline and Fall of the Case Against Same-Sex Marriage, 2 U. of St. Thomas L. J. 5 (2005). 
contraception in their early 20s, prolonged their educations, and delayed marriage and parenthood. Similar behavior by more vulnerable populations would make them better off. For opponents of homosexuality, relying on consequences is building one's house on dynamite.

The intrinsic good of one-flesh union

Geach states the first claim succinctly: "the marriage act has an intrinsic meaning which does not depend on human convention, but which is part of the fabric and constitution of our nature, so that by damaging our sense of the significance of our sexuality we undermine that fabric and undo that constitution." ${ }^{4}$ Part of the meaning of marriage as she understands it is that it is the only legitimate use of the sexual function. Among the acts which distort the meaning of the marriage act are sex outside of marriage, contraception, divorce, masturbation, sexual fantasy, and homosexual conduct. These are categorically immoral, and never permissible under any circumstances.

The view she puts forth has already been made prominently by the new natural law theorists (hereinafter NNL), the theologian Germain Grisez and the legal scholar and philosopher John Finnis, and further developed by Robert P. George, Gerard Bradley, and Patrick Lee. ${ }^{5}$ Central to their argument is the view that sex is only morally licit within marriage, which is "a basic and irreducible good perfective of human persons." 6 I cannot review their entire argument here, ${ }^{7}$ but will focus on their account of

\footnotetext{
${ }^{4}$ Mary Geach, Lying With the Body, 91 The Monist 523, 525 (2008). 5 She acknowledges her affinity with NNL in id. at 527.

${ }^{6}$ Robert P. George, What's Sex Got to Do With It? Marriage, Morality, and Rationality, in The Meaning of Marriage: Family, State, Market, and Morals 142, 169 (Robert P. George \& Jean Bethke Elshtain eds., 2006).

7 I have done so elsewhere. See Koppelman, Decline and Fall; Andrew Koppelman, The Gay Rights Question in Contemporary American Law 80-93 (2002); Andrew Koppelman, Is Marriage Inherently Heterosexual?, $42 \mathrm{Am}$. J. Jurisprudence 51 (1997). Since I wrote these pieces, Lee and George have elaborated considerably on their claims about the disintegrating effects of the pursuit of pleasure in Patrick Lee and Robert P. George, Body-Self Dualism in Contemporary Ethics and Politics (2007), and they specifically respond to my objections in id. at 191-93. I cannot address their general argument here. I note, however, that their claims about the disordered character of nonmarital sex are parasitic upon their claims, which I do address below, that there is a distinct good achieved by the heterosexual couple, even if that couple is known to be infertile. If that distinct good cannot intelligibly be shown,
} 
the distinctive good that they think is achieved by heterosexual marriage.

Marriage, Grisez argues, is an irreducible human good, because it constitutes "a full communion of persons: a communion of will by mutual covenantal commitment, and of organism by the generative act they share in". 8 Communion of will consists of a mutual commitment to an exclusive and indissoluble partnership, while organic communion consists in the fact that - here comes the boldest move of the NNL theorists, one that Geach does not make -- when husband and wife engage in procreative marital intercourse, they literally become a single organism.

For NNL "each animal is incomplete, for a male or a female. . . is only a potential part of the mated pair, which is the complete organism . . capable of reproducing sexually. This is true also of men and women: as mates who engage in sexual intercourse suited to initiate new life, they complete each other and become an organic unit. In doing so, it is literally true that 'they become one flesh' (Gn 2.24)".9 What looks like a metaphor in Genesis becomes a simple statement of fact in NNL. The married couple, when mating, "truly become biologically one, one body."10

Nonmarital sexual acts, whether homosexual or heterosexual, cannot achieve this bodily unity. At best, they achieve the illusory experience of unity. "For a truly common good, there must be more than experience; the experiences must be subordinated to a truly common act that is genuinely fulfilling". ${ }^{11}$ When gay couples (or even married heterosexual couples) achieve sexual satisfaction by means other than marital intercourse, the act "is really an instance of mutual masturbation, and is as selfalienating as any other instance of masturbation." Thus Finnis writes of sex between unmarried people that their reproductive organs cannot make them a biological (and therefore personal) unit. . . Because their activation of . . . their reproductive organs cannot be an actualizing and experiencing of the marital good. . . it can do no more than provide each partner with an

then, whatever the significance of pleasure might be, there is no radical difference between marital heterosexual sex and other kinds of sexual conduct.

8 Germain Grisez, The Way of the Lord Jesus, vol. 2: Living a Christian Life 580 (1993).

9 Id. at 570 .

10 Lee and George, Body-Self Dualism, at 199.

11 Id. at 146 . 
individual gratification. For want of a common good that could be actualized. . . by and in this bodily union, that conduct involves the partners in treating their bodies as instruments to be used in the service of their consciously experiencing selves; their choice to engage in such conduct thus dis-integrates each of them precisely as acting persons. ${ }^{12}$

Homosexual acts are wrong not only because they violate integrity, but also because they "violate the good of marriage". ${ }^{13}$ Choosing nonmarital sex "damages the body's capacity for the marital act as an act of self-giving which constitutes a communion of bodily persons."14 This damage is "a damage to the person as an integrated, acting being; it consists principally in that disposition of the will which is initiated by the choice to engage in" such sexual activity. ${ }^{15}$ Consider a married man who has never committed adultery, but who might be willing to do so if, say, his wife were unavailable when he felt strong sexual desire. The exclusivity of the man's sex with his wife is not an expression of commitment, because conditional willingness to commit adultery precludes commitment. He is thus motivated even in marital intercourse by something other than the good of marriage (which takes its meaning in part from being the only legitimate use of the sexual powers). This is why Finnis claims that the "complete exclusion of nonmarital sex acts from the range of acceptable and valuable human options is existentially, if not logically, a precondition for the truly marital character of one's intercourse as and with a spouse". ${ }^{16}$ When one damages that precondition, one damages marriage, since "to damage an intrinsic and necessary condition for attaining a good is to damage that good itself". ${ }^{17}$

The new natural lawyers's claims have been subjected to withering criticism. ${ }^{18}$ Here $I$ will focus on just one

12 John M. Finnis, Law, Morality, and "Sexual Orientation", 69 Notre Dame L. Rev. 1049, 1066-67 (1994).

13 Grisez, 2 The Way of the Lord Jesus at 633.

14 Id. at 650 .

15 John M. Finnis, The Good of Marriage and the Morality of Sexual Relations: Some Philosophical and Historical Observations, $42 \mathrm{Am}$. J. Jurisprudence 97, 119 (1997).

16 Id. at 123 .

17 Grisez, 2 The Way of the Lord Jesus, at 650-51.

18 Stephen Macedo, Homosexuality and the Conservative Mind, 84 Geo. L. J. 261 (1995); Michael J. Perry, The Morality of Homosexual Conduct: A Response to John Finnis, 9 Notre Dame J. L. Ethics \& Pub. Pol'y 41, (1995); Paul J. Weithman, Natural Law, Morality, and Sexual 
difficulty, the peculiar claim that the married couple become a single organism. This is an odd claim in any case, but it becomes even odder when NNL insists that it is also true of an infertile heterosexual couple.

Even when a heterosexual couple cannot reproduce, Finnis writes, the "union of the reproductive organs of husband and wife really unites them biologically (and their biological reality is part of, not merely an instrument of, their personal reality)". ${ }^{19}$ Finnis explains that the infertile married couple

who unite their reproductive organs in an act of sexual intercourse which, so far as they can make it, is of a kind suitable for generation, do function as a biological (and thus personal) unit and thus can be actualizing . . . the two-in-one-flesh common good and reality of marriage, even when some biological condition happens to prevent that unity resulting in generation of a child. Their conduct thus differs radically from the acts of a husband and wife whose intercourse is . . sodomitic or by fellatio or coitus interruptus. ${ }^{20}$

The radical difference here is difficult to discern. That sterile heterosexual coitus could have been procreative in some other possible world does not distinguish it from homosexual sex.

The NNL distinction turns on the form of the act, about which Lee and George write:

People who are not temporarily or permanently infertile could procreate by performing exactly the same type of act which the infertile married couple perform and by which they consummate or

Complementarity, in Sex, Preference, and Family: Essays on Law and Nature 239-40 (David Estlund \& Martha Nussbaum eds. 1997); Paul J. Weithman, A Propos of Professor Perry: A Plea for Philosophy in Sexual Ethics, 9 Notre Dame J. L. Ethics \& Pub. Pol'y 75 (1995); Martha C. Nussbaum \& Kenneth J. Dover, Dover and Nussbaum Reply to Finnis, in Martha C. Nussbaum, Platonic Love and Colorado Law: The Relevance of Ancient Greek Norms to Modern Sexual Controversies, 80 Virginia Law Review 1515, 1649 (1994); John Corvino, Homosexuality and the PIB Argument, 115 Ethics 501 (2005); Gareth Moore, Natural Sex: Germain Grisez, Sex, and Natural Law, in The Revival of Natural Law: Philosophical, Theological, and Ethical Responses to the Finnis-Grisez School (Nigel Biggar \& Rufus Black 2000); Nigel Biggar, Conclusion, in The Revival of Natural Law; Nicholas Bamforth and David A. J. Richards, Patriarchal Religion, Sexuality, and Gender: A Critique of New Natural Law (2007); and my works cited supra note 7 .

19 Finnis, Law, Morality, and "Sexual Orientation", at 1066.

20 Id. at 1068 . 
actualize their marital communion. The difference between sterile and fertile married couples is not a difference in what they do. Rather it is a difference in a distinct condition which affects what may result from what they do. ${ }^{21}$

I have stated my objection to this before. The core difficulty is that the classification of marital acts, including the infertile heterosexual couple but excluding the homosexual couple, is arbitrary:

What sense does it make to postulate one type of sexual activity as normative in this way, so that heterosexual intercourse is held to be an act of reproductive kind even if reproduction is not intended and is known to be impossible? Why is it not equally plausible to say that all acts of seminal ejaculation are reproductive in kind, or to say that no acts of seminal ejaculation are reproductive in kind, and that reproduction is only an accidental consequence that may ensue under certain conditions? There is nothing in nature that dictates that the lines have to be drawn in any of these ways. ${ }^{22}$

An infertile reproductive organ remains taxonomically a reproductive organ, but if it is infertile, it is not a reproductive organ "in the sense of power or potential."23 It is not a reproductive organ in that sense. "A sterile person's genitals are no more suitable for generation than an unloaded gun is suitable for shooting. If someone points a gun at me and pulls the trigger, he exhibits the behavior which, as behavior, is suitable for shooting, but it still matters a lot whether the gun is loaded and whether he knows it."24

The new natural lawyers' recent work largely repeats their view rather than defending it against objections, ${ }^{25}$

21 Lee \& George, What Sex Can Be, at 150 .

22 Koppelman, The Gay Rights Question, at 86-87.

23 Id. at 88 .

24 Id.

25 Gerard V. Bradley, Same-Sex Marriage: Our Final Answer?, 14 Notre Dame J. L. Ethics \& Pub. Pol'y 729 (2000); John Finnis, "An

Intrinsically Disordered Inclination," in Same-Sex Attraction: A Parents' Guide 89 (John F. Harvey \& Gerard V. Bradley eds. 2003); Robert P. George, Judicial Usurpation and Sexual Liberation: Courts and the Abolition of Marriage, 17 Regent U. L. Rev. 21 (2004); Gerard V. Bradley, Law and the Culture of Marriage, 14 Notre Dame J. L. Ethics \& Pub. Pol'y 189 (2004); Patrick Lee, The Human Body and Sexuality in the Teaching of Pope John Paul II, in John Paul II's Contribution to Catholic Bioethics 107 (Christopher Tollefsen ed. 2004); John Finnis, Marriage: A Basic and Exigent Good, 91 The Monist 388 (2008); Gerard V. Bradley, What's In a Name? A Philosophical Critique of 'Civil 
but Lee and George have responded to me in some detail. ${ }^{26}$ In response to the problem of the infertile couple, they write:

But our claim is not that in a marital act, one must intend to procreate, hope to procreate, or even think that procreation is in these circumstances possible. Our claim is that a marital act is an act in which a man and woman, as complementary, become bodily and organically one, in that they jointly perform a single act, single in that it is an act that is biologically oriented to procreation, though some other condition in the agents may prevent the completion of that orientation in this act. ${ }^{27}$

It is not clear what is doing the work here. Perhaps it is the proposition that the couple "become bodily and organically one" because they are engaged in a reproductive type of act. But they do not become a single organism even if they happen to conceive.

Lee and George concede that "[n]ot every instance of two entities sharing in an action are instances of two entities becoming biologically one." The act of reproduction, however, can be actualized only in cooperation with the opposite sex of the species. The reproductive bodily parts are internally oriented toward actuation together with the bodily parts of the opposite sex. So, although the bodily parts of the male and the female are not interdependent for their continued life (as the bodily parts are to each other in a male

Unions' Predicated Upon a Sexual Relationship, 91 The Monist 606 (2008). George and Bradley have also invoked these arguments to justify the criminalization of homosexual sex and a constitutional amendment against same-sex marriage. Robert P. George, The Concept of Public Morality, 45 Am. J. Jurisprudence 17, 30-31 (2000); Robert P. George, One Man, One Woman: The Case for Preserving the Definition of Marriage, Wall St. J., Nov. 28, 2003; Gerard V. Bradley, Stand and Fight: Don't Take Gay Marriage Lying Down, National Rev., July 28, 2003; Robert P. George, The 28 th Amendment, National Rev., July 23, 2001.

26 Patrick Lee and Robert P. George, Body-Self Dualism in Contemporary Ethics and Politics 191-93, 197-204 (2007); Robert P. George, What's Sex Got to Do With It? Marriage, Morality, and Rationality, in The Meaning of Marriage: Family, State, Market, and Morals 142 (Robert P. George \& Jean Bethke Elshtain eds., 2006); see also Patrick Lee, Marriage, Procreation, and Same-Sex Unions, 91 The Monist 422 (2008); Patrick Lee \& Robert P. George, What Male-Female Complementarity Makes Possible: Marriage as a Two-in-One-Flesh Union, 69 Theol. Stud. 641 (2008) (responding to similar objections).

27 Lee and George, Body-Self Dualism, at 204. 
organism or the bodily parts to each other in a female organism) there is a real biological unity between them. ${ }^{28}$

The logic packed into the word "So" at the beginning of the final sentence is obscure. In reproduction, two entities share in a bodily action. That does not mean that they become one, even though the action they perform could not be performed by either of them individually. Two pianists playing a four hands piece do not become biologically one, even though they are using parts of their bodies in a complementary way.

To defend his claim of organic unity, George cites a thought experiment proposed to him in conversation by Grisez:

Imagine a type of bodily, rational being that reproduces, not by mating, but by some individual performance. Imagine that for these beings, however, locomotion or digestion is performed not by individuals, but only by biologically complementary pairs that unite for this purpose. Would anybody have difficulty understanding that in respect of reproduction the organism performing the function is the individual, while in respect of locomotion or digestion the organism performing the function is the united pair? Would anybody deny that the unity effectuated for purposes of locomotion or digestion is an organic unity ${ }^{29}$

The thought experiment does not lead where Grisez

intends. Let's suppose, to specify, that these beings have half the body of a human being, clumsily hopping about on a single leg, fulfilling the threat of Zeus in Aristophanes's speech from Plato's Symposium. ${ }^{30}$ In this fashion they can barely move at all by themselves (they keep falling on their one-eyed faces), while they can walk very efficiently if a left half and a right half grab each other's upper bodies tightly.

Whey they walk, thus connected, certainly it is the united pair that is walking. It does not follow that they are "an organic unity," much less a single organism. They are simply cooperating in a joint task. Two organisms engaged in symbiotic cooperation remain two organisms. In a lichen, the fungus and the algae do not become a single organism.

28 Id. at $183 \mathrm{n} \cdot 15$.

29 George, What's Sex Got to Do With It? at 158-59.

30 Plato, Symposium 190d. 
Even if the couple does not become a single organism, George can still say that their coitus "is an act that is oriented to procreation." But it is obscure how an act can be oriented to procreation when procreation is known to be, not merely unlikely, but actually impossible. If the two Aristophanean halves grabbed hold of each other and waved their legs while suspended in midair on a bungee, would their action be oriented to locomotion? Could the locomotive character of their motion be a source of its goodness? Would that goodness be absent if two left-sided half-people (who could not walk together) waved their legs together while hanging from the same bungee?

George notes that coition is only one part of the reproductive process, and that as a part of the process, it can be completed by the infertile couple:

In performing this first part of the reproductive process together, the male and the female act as a single unit, even where in many cases the second part of the process cannot (for any of a variety of causes) be completed. • . A condition, or even a defect, which prevents the second part of the process cannot change the fact that the male and the female did actually unite - become organically one - in the first part of that process. If conception does occur, it won't be until several hours later (at the earliest); and whether they now become one cannot depend on events that occur only later. ${ }^{31}$

There is a deep confusion here. My action can make sense as part of a process, can take its meaning from its role in facilitating that process, only if the process is known to be capable of completion. This is true even if the success of the project is unlikely. But it is not true if success is impossible.

A surgeon trying to save the life of a gravely sick patient is engaged in the practice of medicine even if the patient's death is almost certain. No guarantee of success is necessary. (Little human endeavor comes with a guarantee of success.) So long as the patient is alive and the surgery even marginally increases the likelihood of the patient's survival, then the surgeon's behavior makes perfect sense. He is engaged in a medical-type act. Whether it is a medical-type act now cannot depend on events that occur only later, such as the patient's recovery.

31 George, What's Sex Got to Do with It? at 162. 
But what would we think if the surgeon performed exactly the same actions, involving the same bodily motions, when the patient is already dead? George writes that

the only behavior which the partners have direct control over is coition itself, performed in such a way as to fulfill the behavioral conditions of reproduction. This is the only act, the only behavior, which they directly perform, and it disposes them to procreation (rather than being the direct act of procreating). Thus, the other conditions (an adequate sperm count, time of ovulation, etc.) are not part of the couple's behavior, not part of what they do. ${ }^{32}$

Try this logic on the surgeon as he operates on the corpse. All of George's verbal moves are available here, but the result will be pretty weird:

The only behavior which the surgeon has direct control over is surgery itself, performed in such a way as to fulfill the behavioral conditions of the patient's recovery. This is the only act, the only behavior, which he directly performs, and it disposes him to healing (rather than being the direct act of healing, which in every case of medicine may or may not

happen). Thus, the other conditions (a patient who is alive at the time of the surgery, etc.) are not part of the surgeon's behavior, not part of what he does. George adds that "a second reason" why infertile spouses" marital acts "are reproductive in kind is that they bespeak and bear witness to the intrinsic goodness of marriage, the kind of community that is naturally fulfilled by the bearing and rearing of children." ${ }^{33}$ But this is not a second reason at all. It is the first reason restated. If the couple do not unite organically, if their actions aren't intelligible because of their relationship to reproduction, then there is no "intrinsic goodness of marriage," in the sense in which he means these words, for their acts to bespeak and bear witness to.

It is one of the facts about the human capacity for signification that anything can bespeak anything. You can sprinkle the fairy dust anywhere you like: you could attribute goodness only to the sex acts of Chicago White Sox fans who copulate on Tuesdays. But the new natural lawyers have not identified a distinctive, intelligible

32 Id. at 163 .

33 Id. at 164-65. 
category of action to which intrinsic goodness can be shown uniquely to attach.

Geach's new strategy

Geach does not rely on the claim that the married heterosexual couple unites biologically. ${ }^{34}$ She does, however, think that their coupling matters because of its relation to procreation. Her central claims are that there is a distinctive sexual virtue for human beings, that this virtue marks the boundaries of permissible sexual conduct in the ways earlier enumerated, and that this is so for two related reasons: firstly, because the sense of marriage as an integral whole is part of the psychic makeup of the virtuous man, a part which is damaged when we use our bodies in a way which treats this whole as a collection of separable parts, and secondly, because it belongs to the good order of human society that marriage should be presumable as the sexual relation. ${ }^{35}$

She agrees with NNL that heterosexual marriage, defined as NNL defines it, is an ultimate, noninstrumental good. Her claims about sexual virtue are parasitic on this ultimate value claim. Her task, then, is to persuade the reader to see the distinctive human end that she sees.

This presents a rhetorical challenge, for her as much as for NNL. The basic problem, George observes, is that "intrinsic values, as ultimate reasons for action, cannot be deduced or inferred. We do not, for example, infer the intrinsic goodness of health from the fact, if it is a fact, that people everywhere seem to desire it. . . We see the point of acting for the sake of health, in ourselves or in others, just for its own sake, without the benefit of any such inference." ${ }^{36}$ If the value of health is defended as a means to some other end, then the question will arise why that is a good thing; the chain of reasoning has to conclude somewhere, with some good that is deemed good in itself and not as a means to something else. The intrinsic nature of intrinsic goods can only be defended dialectically:

34 She offers formulations that approach this claim in Lying at 524 and 548-49, but it is peripheral to her argument. Unlike the NNL theorists, her argument would not be weakened if it were rejected. 35 Geach, Lying, at 528 .

36 Robert P. George, Recent Criticism of Natural Law Theory, in In Defense of Natural Law 48 (1999). 
While they may be defended by dialectical arguments designed either to rebut arguments against them, or to show up the defects or inadequacies of ethical theories that attempt to do without them, they cannot themselves be deduced or inferred or derived from more fundamental premises. One cannot argue one's way to them (the way one can, on the basis of more fundamental premises, argue one's way to a conclusion). The claim that they are selfevident does not imply that they are undeniable or, still less, that no one denies them. What it does imply is that the practical intellect may grasp them, and practical judgment can affirm them without the need for a derivation. (Which is not to say that they can be grasped without an understanding of the realities to which they refer.) ${ }^{37}$

Geach acknowledges the difficulty of demonstrating her core account of the virtue concerned with sex, a virtue that takes its character from both human nature and from the good that sexuality is directed toward. "One can't prove the first principle, in the sense of demonstrating it as the logical consequence of some other principle."38

Instead, she proposes to follow a procedure common in natural science: to "form an hypothesis which covers the facts, and then see whether things do happen in accordance with this hypothesis."39 The evidence that supports her hypothesis is "[t]he benefits of marriage" and, more importantly (since most supporters of gay rights do not deny that heterosexual marriage has benefits), "the ills resulting from disordered sexuality." 40

To begin with, there is the importance, for any human civilization, of an ethic of chastity, especially among

37 Id. at 45 .

38 Geach, Lying, at 529. As she puts it elsewhere: "I don't think we can deduce the need for marriage from first principles about life and friendship: we have to include among the first principles of morality not just the need to pursue these basic goods, but also the existence of marriage, the capacity for which is itself a part of the fabric and constitution of our nature." Mary Geach, Marriage: Arguing to a First Principle in Sexual Ethics, in Moral Truth and Moral Tradition: Essays in Honour of Peter Geach and Elizabeth Anscombe 177, 181 (Luke Gormally ed. 1994).

39 Geach, Lying, at 540 .

40 Id. at 540 . 
women. In all of the world's great civilizations, "the chastity of women is highly valued, and there is also some idea of a corresponding virtue of men." ${ }^{41}$ Female chastity is important so men can know who their children are, and only men who know that will do the hard work of supporting women and children. Fathers also have "the strength and will to control [children] and teach them respect for authority and for law. . . If the men laze around leaving everything to the women, and if the women whore around so that no one knows who his father is, then everything will decay, and the people will no longer respect duly constituted authority and laws but will rather be ruled by servile fear or inarticulate adherence to custom." 42 Civilization requires, then, that "the virtuous of both sexes have a profound state of mind inclining them to faithfulness in marriage." ${ }^{3}$ All of these facts point to the truth of the good of marriage as Geach conceives it. That good "stands to our sexual actions in a relation similar to that in which the truth conditions of a proposition stand to the assertion of it."44 Orientation toward marriage as she understands it explains the state of mind necessary for marital chastity. It also explains and provides a justification for sexual jealousy, ${ }^{45}$ it explains the importance of consent to sex, ${ }^{46}$ it explains why lovers yearn for a permanent union. ${ }^{47}$

Pleasure, on the other hand, is "an aspect, but not an end," ${ }^{48}$ of the marriage act. When it is disconnected from any good of which it could be a part, pleasure is not in itself good. "If someone has such sensations in connection with the pain suffered by others, should we say that, though the pain was bad, his erotic sensations were good? Or that his delight in these sensations was good? Surely not."49 Rather, these sensations are "about something, and what they are about should be appropriate, which we realize

41 Id. at 534

42 Id. at 535. I note in passing the strangeness of the implication that mothers cannot teach children respect for authority.

43 Id. at 536 .

44 Id. at 544 .

45 Id. at 537 .

46 Id. at 537-38.

47 Id. at 539 .

48 Id. at 547 .

49 Id. The example does not prove that pleasure is not in itself good, but only that it is sometimes inextricably joined with something that is very bad. Any good thing that is abused by its possessor is a fit occasion for ambivalence. It would have been better if Hitler had been less clever and resourceful than he was, but intelligence is nonetheless in itself good. 
when we consider how stupid and mad our sexuality can make us. " 50

Miracle, mystery, and authority: Wax

All this evidence about the value of the old sexual ethic, even if it is accepted (I will offer some cautions below), doesn't get Geach to the conclusion she is after. It is consistent with the view, which she rejects, that there is no genuine moral requirement of chastity to which this ethic responds.

It might be that the norm of chastity, as she conceives it, is a socially useful illusion. This is how Friedrich Hayek thought about religious belief. Hayek thought that the persistence of customs conducive to social cooperation was closely tied to the support those customs received from religion. Of course, not all religions had this beneficent effect. "Among the founders of religions over the last two thousand years, many opposed property and the family. But the only religions that have survived are those which support property and the family."51 The process by which the pertinent selection occurred may have been invisible to those who benefited from it. "Customs whose beneficial effects were unperceivable by those practicing them were likely to be preserved long enough to increase their selective advantage only when supported by some other strong beliefs; and some powerful supernatural or magic faiths were readily available to perform this role."52 What matters is that the customs that survived were the ones that "influence[ed] men to do what was required to maintain the structure enabling them to nourish their enlarging numbers." 53 The value of religion, for Hayek, is that it enables people to engage, "peacefully though competitively, in pursuing thousands of different ends of their own choosing in collaboration with thousands of persons whom they will never know." ${ }^{4}$ Hayek himself was an atheist who regarded the notion of God as unintelligible; ${ }^{55}$ he regarded religion as a functionally valuable fiction. For Hayek, cooperation-inducing rules need not be adopted for that

50 Geach, Lying, at 547 .

511 The Collected Works of F.A. Hayek: The Fatal Conceit: The Errors of Socialism 137 (W.W. Bartley III ed. 1988).

52 Id. at 138 .

53 Id. The evolutionary argument is further developed in Friedrich A. Hayek, 2 Law, Legislation, and Liberty: The Mirage of Social Justice 17-23 (1976).

54 Hayek, The Fatal Conceit, at 135.

55 See id. at 139-40. 
purpose: "Neither the groups who first practised these rules, nor those who imitated them, need ever have known why their conduct was more successful than that of others, or helped the group persist." ${ }^{56}$

Something like Hayek's view is evident in the objections to same-sex marriage developed by Amy Wax. ${ }^{57}$ Wax's claims are not the same as Geach's, because she focuses solely on same-sex marriage and does not claim that homosexual sex is per se immoral. Her concern is public mythos, not private conduct.

Wax worries that recognition of same-sex marriage could weaken or transform the conventions surrounding heterosexual marriages:

The fear is that, if the institution of marriage is reshaped to give priority to diversity, choice, and individual prerogatives--and if marital roles are redefined to fit different homosexual and heterosexual lifestyles--then behavior surrounding all marital relations may change in response. Those changes may not be beneficial. For example, if homosexuals are less likely to have children, procreation might become less central to marriage. This might foster a model of marriage that views children as optional or even unimportant. Or, in keeping with past commitments and rhetoric, homosexual couples might place less emphasis on sexual fidelity or be more tolerant of sexual infidelity within their relationships. The existence of a significant number of "open marriage" homosexual couples might affect how heterosexuals view their own commitments, with potentially unsettling or disruptive consequences. ${ }^{58}$

At no point does Wax suggest that the sexual lives of gay people are per se inferior to those of heterosexuals, or in any way immoral. She is simply concerned about the

56 Id. at 21 .

57 Wax distinguishes her view from Hayek's at one point, but she is focusing on his libertarianism, not on his endorsement of religious mystification. Amy L. Wax, The Conservative's Dilemma: Traditional Institutions, Social Change, and Same-Sex Marriage, 42 San Diego L. Rev.1059, 1065 n.16 (2005).

This conservative caution about changing family forms obviously has ramifications beyond marriage. Judge J. Harvie Wilkinson once suggested that the protection of traditional family patterns might justify the criminalization of homosexual sex. J. Harvie Wilkinson III \& G. Edward White, Constitutional Protection for Personal Lifestyles, 62 Cornell L.Rev. 563, 596 (1977).

58 Amy L. Wax, Traditionalism, Pluralism, and Same-Sex Marriage, 59 Rutgers L. Rev. 377, 400-01 (2007) (footnote omitted). 
effect of their acceptance on the broader social ecology. It's really the heterosexuals that she's worried about. The old sexual scripts are a solution to their perennial problems, most prominently the difficulty of forging bonds between fathers and children.

Because most people are incapable of reasoning through every dilemma of social life on their own, they depend on off-the-shelf scripts that define basic duties and provide transparent guidelines for behavior in commonplace social situations. Simple, unyielding rules maximize the chance that persons of limited intellect and self-control will negotiate complex human interactions successfully. As such, these scripts should be as clear and unequivocal as possible. Formal institutions such as marriage, by embodying a simple and transparent set of expectations, help facilitate moral conduct by ordinary people. ${ }^{59}$

Wax values these off-the-shelf scripts for the same reason as Hayek. It is an unhappy fact of social life that most people depend on miracle, mystery, and authority.

For the most part, Wax's focus is not on gay people, but on the feared effects of legitimizing homosexuality on the wider, heterosexual population. However, she does raise concerns about gay people raising children (which will happen more often if gays marry). She cites studies showing that children thrive better when raised by their married biological parents than by other combinations, such as "[c]hildren in single parent families, children born to unmarried mothers, and children in step-families or cohabiting relationships."60 These concerns do not necessarily bar recognition of same-sex marriage: "enhanced risks for children, especially if modest, may not warrant abandoning reforms motivated by a firm commitment to rights and equality."61

These studies, without more, can't provide even mild support for the case against same-sex marriage. Same-sex couples are already raising large numbers of children, and will continue to do so whether or not same-sex marriage is

59 Wax, The Conservative's Dilemma, at 1090.

60 Wax, Traditionalism, Pluralism, at 402, quoting Kristin Anderson Moore, et al., Marriage from a Child's Perspective: How Does Family Structure Affect Children and What Can We Do About It?, Child Trends Research Brief 6 (Jun. 2002). A similar argument is made by Maggie Gallagher, whose argument is critiqued in Koppelman, Decline and Fall. 61 Traditionalism, Pluralism, at 412 . 
recognized. ${ }^{62}$ Withholding recognition just makes these children's lives less stable. Moreover, whatever the deficits of the kinds of households listed, there is no evidence that children raised by same-sex couples do worse than children raised by heterosexual couples. ${ }^{63}$ The household types are too different to support any inference from one to the other. In households with stepfathers, for example, the introduction of a new adult into the household is yet another disruption in children's lives; stepfathers are less likely to be committed to the child's welfare and less likely to be a check on the mother's behavior; they sometimes compete with the child for the mother's time; the mother may be reluctant to share authority with the stepfather. ${ }^{64}$ None of these problems are likely to be present in children of same-sex couples. Wax worries that those children are likely to face other, analogous problems. But if this were true, would there not be some evidence of it?

Her conclusion, on the basis of this evidence, that the heterosexual nuclear family is the "gold standard" for family form, ${ }^{65}$ and that "[c]hildren do best if their entire childhood is spent with both their biological parents," ${ }^{66}$ is like saying that, given that a poodle is bigger than a squirrel or a butterfly, it follows that the poodle is bigger than any other animal.

To Hell in a Handbasket, and Back

62 The 2000 Census found that nearly 600,000 same-sex couples reported themselves as "unmarried partners," compared with 145,130 such households counted by the 1990 Census. The number is probably a substantial undercount, since many gay people are unwilling to share this information with the government. Same-sex households were reported in 99.3\% of U.S. counties in 2000, and were about as racially diverse as the population as a whole. Children were present in $34 \%$ of lesbian couples and 22\% of gay male couples. (By comparison, 46\% of married heterosexual couples were raising children.) Sean Cahill, Same-Sex Marriage in the United States: Focus on the Facts 43-46 $(2004)$.

63 See Abbie E. Goldberg, Lesbian and Gay Parents and Their Children: Research on the Family Life Cycle (2010); Judith Stacey \& Timothy J. Biblarz, (How) Does the Sexual Orientation of Parents Matter?, 66 Am. Soc. Rev. 159 (2001).

64 Sara McLanahan and Gary Sandefur, Growing Up With a Single Parent: What Hurts, What Helps 29 (1994). This book is cited in Wax, The Conservative's Dilemma, at $1087 \mathrm{n} .79$. She acknowledges these specific issues in Traditionalism, Pluralism, at 409.

65 Wax, Traditionalism, Pluralism, at 407.

66 Id. at 409 . 
Geach, on the other hand, thinks that homosexuality is immoral regardless of its social effects. Even private homosexual conduct that no one else ever knows about is immoral.

Geach's claim would be stronger if it could be shown, not merely that the ethic she describes is useful for some societies, but that human society cannot flourish without it. If a sexual ethic is merely a noble lie, then people can dispense with it if they are able to consciously and directly pursue the purpose that the noble lie serves. Hayek thought that religion inadvertently served the cause of economic growth, but his own philosophy aimed at growth without relying on what he regarded as childish mystifications, and he has many followers. If, on the other hand, it turns out that those who turn away from the ancient ways inevitably come to wreck, this would be evidence that those ways are, indeed, part of the fabric of human nature.

So Geach moves on, to enumerate the pathologies produced by our present civilization's relaxed sexual mores. ${ }^{67}$ The relaxed attitude toward masturbation and sexual fantasy is destructive, because orgasmic fantasy "seriously undermines one's sense of reality, and damages one's ability to empathise with other people, because the use of one's sexuality signifies another party, and one has been using it when no other party was present." 68 This "explains the nastiness of some adolescents, and of some single people."69 The absence of clear conventions about the limits of what unmarried men may do generates the problem of date rape. ${ }^{70}$ The acceptance of homosexuality damages all relations between persons of the same sex, by making non-sexual friendship harder than it once was because it is now tainted by sexual fear and avoidance. ${ }^{71}$

67 The new natural law theorists often help themselves to this kind of claim; see, e.g., Finnis, Marriage: A Basic and Exigent Good, at 402, Lee, Marriage, Procreation, and Same-Sex Unions at 432, George, What's Sex Got to Do With It? at 147-49; but it is peripheral to their argument, which does not depend on the existence of any such pathologies.

68 Geach, Lying, at 539.

69 Id. at 540 .

70 Id. at $537-38$.

71 Id. at 532. Her points about homosexuality are not strictly speaking part of her argument, as she states them before making the case for her first principle, and writes that in making that case she will "leave sodomy to one side." Id. at 531. Nonetheless, her allegations about homosexuality, if accepted, do strengthen her case that modern sexual mores are pathological, so they must be rebutted if her claims are to be answered. 
The acceptance of homosexuality tends to place society on a path of "decay to the point where there is no separate class of homosexuals, but one undifferentiated lustful multitude."72 Most alarmingly, "where there is a widespread abuse of human sexuality, life will come to seem meaningless and many will commit suicide."73 And, in fact, "in our comfortable and apparently happy society . . . suicide happens a great deal."74 Our society "is in a state of decadence, and with its aging population and weapons of mass destruction seems to be heading towards its end."75 These are categorical claims about the destructive effects of sexual vice on human nature. No Hayekian elite could evade its malign power.

Geach despises cruelty and self-deception, and cares urgently about the future of civilization. Her humane impulses are admirable. But one must have a heart of stone to read her catalogue of horrors without laughing. Her theories about the catastrophic effects of masturbation are only the latest of a long series of delusions about the practice, all focusing (as she does) on the fear that young people would withdraw entirely from society, pursuing pleasures that were asocial and autarkic. ${ }^{76}$ Just how much special discernment does it really take to avoid raping your date? I can't think of a single instance in which I've experienced the hesitation with my friends (including my gay friends) that Geach frets about. As the sexual revolution has unfolded in the United States and England, the suicide rate has been steadily declining. ${ }^{77}$

The new middle class ethic

\footnotetext{
72 Id. at 533

73 Id. at 544 .

74 Id.

75 Id. at $556 \mathrm{n} .17$.

76 See Thomas W. Laqueur, Solitary Sex: A Cultural history of Masturbation (2003); Walter Kendrick, The Secret Museum: Pornography in Modern Culture 138-43 (1988); Helen Lefkowitz Horowitz, Rereading Sex: Battles over SeXual Knowledge and Suppression in Nineteenth Century America 92-93, 97-107, 394-403 (2003).

77 U.S. Department of Health and Human Services, Centers for Disease Control and Prevention, Health, United States, 2008, at 258-60, Table 45, available at http://www.cdc.gov/nchs/data/hus/hus08.pdf (visited July 22, 2009); National Mental Health Development Unit, National Suicide Prevention Strategy for England, Annual Report on Progress 2008, at 13-14 ("The suicide rate for the year 2007, the most recent available, was the lowest recorded."), available at http://www.nmhdu.org.uk/silo/files/national-suicide-preventionstrategy-for-england--annual-report-on-progress-2008.pdf (visited July $22,2009)$.
} 
Geach and Wax are right to ask about the costs of relaxing the old rules. As noted earlier, Wax has plenty of data that show that children tend to do best when raised by their biological parents, and that single motherhood is especially hard on children. Both of them are right that it would be a mistake to discard the old ethic and replace it with an ethic of individual self-fulfillment, leaving men free to scatter their seed at will.

Society needs an ethic that binds fathers to children. But there is more than one candidate for that job. The story of the modern sexual revolution is not merely the story of the decay of the old ways. It has also seen the emergence of a new ethic, one that in many ways produces stronger, more functional families that serve children's needs better than the old model.

Naomi Cahn and June Carbone observe that two different family systems, presupposing different norms, now exist in the United States. The older, more traditional model encourages marriage relatively soon after (if not before) the beginning of sexual activity, identifies responsible childbearing with family form rather than economic self-sufficiency or emotional maturity, and embraces more authoritarian models of parenting and the state -- both should be able and willing to intervene to promote the "right" moral values. . . \{A]bstinence outside of marriage is a moral imperative, the shotgun marriage is the preferred solution to an improvident pregnancy, and socialization into traditional gender roles is critical to marital stability. Abortion is an abomination not only because it violates religious teachings about the beginning of life, but also because it represents a determination to evade the consequences of immoral conduct. And gay marriage is, if anything, worse than abortion - the symbol of at the ability to flout moral teachings in the name of individualism and choice. ${ }^{78}$

This model remains prevalent in much of the United States. But it has costs. Where it prevails, divorce rates are the highest in the country, because early marriages are the most likely to fail. Teen pregnancy and single motherhood are frequent. The problem is that, although this ethic has considerable continuing power, it is in decay. Its enforcement mechanisms have weakened. Unhappy couples can

78 Naomi Cahn \& June Carbone, Red Families v. Blue Families, George Washington Law School Working Paper, Aug. 16, 2007, at 3, available at http://papers.ssrn.com/sol3/papers. cfm?abstract id=1008544. 
no longer be forced to stay together, and teenagers can't be prevented from having sex.

At the same time, a new sexual ethic has emerged. This newer model, which Cahn and Carbone call the "new middle class ethic,"

involves less control of sexuality, celebrates more egalitarian gender roles, and promotes financial independence and emotional maturity as the sine qua non of responsible parenthood. The hallmarks of the new system's success are lower rates of divorce and teen births; its weaknesses may ultimately be falling fertility and high percentages of the population living alone. In this new model, abstinence is unrealistic, contraception is not only permissible, but morally compelled, and abortion is the necessary (and responsible) fallback. ${ }^{79}$

Delayed childbearing facilitates more education, which in turn leads to higher incomes later in life. The newer model is no less functional than the old one. Indeed, from the standpoint of child welfare, it has obvious advantages, since it produces less divorce and more mature parenting.

The new model is most prevalent among the most educated classes, who have the highest incomes. The differences are starkly revealed in patterns of single childbearing. In 1960, about 14\% of mothers in the bottom education quartile were single, compared with 4.5\% of mothers in the top quartile. By 2000, the respective percentages were 43\% and 7\%. College-educated women are more likely to marry than other women, and less likely to divorce. The disparity appears to have much to do with delayed childbearing by educated women, which in turn is the result of contraception and abortion. ${ }^{80}$

Integral to this model is greater tolerance of homosexuality. Since this model separates sex from reproduction and values recreational sex, it is not particularly threatened by sex that manifestly has nothing to do with procreation. Tolerance for homosexuality

79 Id. at 2. Cahn and Carbone identify these two models with the states that voted Democratic or Republican in the 2004 election, which they acknowledge is an oversimplification. Both models have some cultural power, and influence the shape of family law, in every state in the country.

80 Sara McLanahan, Diverging Destinies: How Children are Faring Under the Second Demographic Transition, 41 Demography 607 (2004); see also David T. Ellwood \& Christopher Jencks, The Uneven Spread of SingleParent Families: What Do We Know? Where Do We Look for Answers?, in Social Inequality 3 (Kathryn M. Neckerman ed. 2004). 
correlates strongly with high levels of education and income. ${ }^{81}$

The greater stability of these high-income families is directly related to their abandonment of the ethic that Geach and Wax are hoping to preserve. Their children do better because the parents have separated sex from reproduction. Support for gay rights will not corrode these families. Many of them already support gay rights, and they are doing fine. ${ }^{82}$

Wax thinks that "[f]amily disintegration is almost surely the product of a multi-pronged assault on conventional strictures and understandings from many quarters, with factors like the availability of birth control, changes in divorce laws, feminism, the sexual revolution, and the courts' recognition of children's and parental rights outside of marriage playing some role."83 The phenomena she describes are, however, equally present in the top-quartile and bottom-quartile families, and cannot explain the differences between them. In fact, the upper-income families have replicated the statistics of 40 years ago, and in some respects their children are doing even better: their households are more prosperous, and they spend more time with their fathers. ${ }^{84}$

The poorest Americans do have a tendency (only a tendency; more than half of bottom-quartile mothers are married) to exhibit precisely the kind of sexual ethic that Geach fears, with the disastrous consequences that she predicts. Men casually impregnate women. The women raise the children with difficulty. The men are disconnected from the next generation. The children, especially the boys, are poorly socialized. The pattern repeats from one generation to the next.

\footnotetext{
81 A 2003 study by the Pew Research Center found that 44\% of college graduates, but only 23 of high school dropouts, supported same-sex marriage; 40\% of those with incomes above $\$ 75,000$, but only 32\% of those making less than $\$ 20,000$, had that view. Pew Research Center For The People \& The Press, Religious Beliefs Underpin Opposition to Homosexuality (Nov. 18, 2003), at 21 .

82 On the basis of a model much like Wax's, some scholars have claimed that recognition of same-sex marriage in some jurisdictions has led to the decline of heterosexual marriage in those jurisdictions. Those claims have not withstood examination. See M. V. Lee Badgett, When Gay People Get Married: What Happens When Societies Legalize Same-Sex Marriage (2009); William N. Eskridge, Jr. \& Darren R. Spedale, Gay Marriage: for Better or for Worse?: What We've Learned from the Evidence (2006).

83 The Conservative's Dilemma at 1086.

84 McLanahan at 608 .
} 
The causes of these patterns are not well understood. One survey concludes that the most widely cited papers are "those that disprove a popular explanation, not those that support one." 85

What does appear clear is that the greater prevalence of unmarried motherhood among the poor is caused, in part (no one knows how large a part), by the vestiges of the old ethic, which has decayed unevenly. Prohibitions that were functional in context have become pernicious in new circumstances. The stigma of using birth control has, for some populations, decayed more slowly than the stigma of premarital sex: sex is something unexpected that happens to you, while contraception identifies you as a bad girl who plans for sex. ${ }^{86}$ The stigma of unwed motherhood is sometimes felt less strongly than the stigma of divorce. ${ }^{87}$ The unavailability of contraception to low-income women also increases the likelihood of pregnancy, ${ }^{88}$ and abstinence-focused sex education increases the likelihood that a girl will not even know how to contracept when she has her first sexual experience. ${ }^{89}$

Among the poorest Americans, there is a third sexual ethic, which is more tolerant of childbearing outside of marriage than either of the other two. (This is less distinctively an ethic than the other two, since it is not so much a norm of childbearing as a pattern of response to births that are often unplanned and unwelcome. What matters here is that it cannot be conflated with either of the other two. ${ }^{90}$ ) It is not, however, Geach's nightmare of a world in which people feel contempt for marriage.

Poor Americans have the same high expectations for a marriage partner and an ideal marital relationship that rich Americans do. They do not, however, regard marriage as a prerequisite for childbearing, and they think that having a child together is not a sufficient reason to

85 Ellwood \& Jencks, The Uneven Spread of Single-Parent Families, at 3. 86 Kristin Luker, Taking Chances: Abortion and the Decision Not to Contracept (1975).

87 Kathryn Edin \& Joanna M. Reed, Why Don't They Just Get Married? Barriers to Marriage among the Disadvantaged, 15 The Future of Children 117 (2005). One low-income mother declared, "I don't believe in divorce. That's why none of the women in my family are married!" Id. at 125 .

$88 \mathrm{~J} . \mathrm{J}$. Frost et al., Improving Contraceptive Use in the United States, Guttmacher Institute: In Brief (2008), available at http://www. guttmacher.org/pubs/2008/05/09/ImprovingContraceptiveUse.pdf (visited Nov. 23, 2009).

89 See John Santelli et al., Abstinence and abstinence-only education: a review of US policies and programs, $38 \mathrm{~J}$. Adolescent Health 72 (2006). 90 Thanks to June Carbone for helpful conversation on this point. 
marry. Nor is cohabitation: one large study of children of urban unmarried parents found that 83 percent of out-ofwedlock births to adult women were to romantically involved couples, about half of which were living together when the child was born. ${ }^{91}$ Rather, they tend to think that marriage should be reserved for couples who can afford a mortgage on a home, a car, some savings, and money to pay for a wedding. Couples who eventually meet these economic goals do tend to marry once they have done so.

The low marriage rate is in part a product of circumstances. ${ }^{92}$ The poor marry at a lower rate because most are unable to meet this higher standard. If they could meet it, the standard would do less damage. A substantial obstacle is many low-income men's unstable employment, low educational attainment, drug use, violence, and frequent encounters with the criminal justice system. ${ }^{93}$ That, in turn, is the product of soft employment markets, bad schools, and drug laws that send huge number of young men to prison without significantly controlling drug markets. Poor women's sexual behavior is in many ways a rational response to these circumstances. College education is out of the question for many, and they perceive no reason to delay childbearing. Since life expectancy is short, there are also substantial costs to delay.

A different ethic about sex might help some of these these people. Either of the two other American models would be an improvement. Under the old model, they would abstain from sex until they are married, and they would delay marriage until their early twenties. Under the new middle-class model, they would be sexually active during those years, but would carefully use contraception. Which ethic do you suppose is an easier sell in contemporary America? ${ }^{94}$

91 Id. at 120 .

92 And nothing I write here should be construed to support the preposterous but widespread canard that if only these people changed their sexual behavior, they would stop being poor. For description and critique, see Michael Brown et al., Whitewashing Race: The Myth of a Color-Blind Society 66-103 (2003); Dorothy Roberts, Killing the Black Body: Race, Reproduction, and the Meaning of Liberty 202-45 (1997).

93 See generally id.

94 Geach, of course, can't seriously consider the new model as a solution, since she thinks that premarital sex, contraception, and abortion are categorically immoral. Many Americans agree with her about sex and abortion, but not about contraception. About 40\% think that sex outside of marriage is morally wrong; see http://www.gallup.com/poll/117328/Marriage.aspx (visited July 29, 2009); and 51\% of Americans describe themselves as "pro-life," though 
Wax is well aware of the class divergence in childbearing patterns that I have described here. She describes it herself, in an article that is not explicitly about same-sex marriage, but which concludes with the claim that these patterns are "reason to question our enthusiasm for innovative family forms and to support the revival of marriage and traditional family structures."95 Her own data indicate, however, that it is precisely the more innovative family form - the "new middle class ethic," which needs no revival - that is most successfully looking after children's needs in contemporary America. Her caution that we should focus on "what actually works in practice to help shape human choice and nurture the most desirable human relationships" ${ }^{96}$ is pertinent here.

The new middle-class ethic, to the extent that it is tolerant of same-sex unions, is a departure from the core, traditional purposes of marriage. Maggie Gallagher, who opposes same-sex marriage for reasons much like Wax's, correctly observes that marriage came into existence, and primarily continues to function, "to manage the procreative consequences of sexual attraction between men and women."97 Same-sex marriage (absent children, although in fact children are often present) does not directly serve that function. But the real question is whether the goods that have traditionally been realized (when all went well) in that practice can also be realized in other social units that don't correspond to the traditional definition. ${ }^{98}$

only 44\% think that abortion should be legal in few or no

circumstances. Lydia Saad, More Americans "Pro-Life" Than "Pro-Choice" for First Time, May 15, 2009, http://www.gallup.com/poll/118399/MoreAmericans-Pro-Life-Than-Pro-Choice-First-Time.aspx (visited Nov. 20, 2009). On the other hand, birth control is supported by 93 percent of American adults, including 90 percent of Catholics. New Harris Poll Finds Different Religious Groups Have Very Different Attitudes To Some Health Policies and Programs, Harris Poll \#78, October 20, 2005, available at

http://www.harrisinteractive.com/harris poll/index.asp?PID=608 (visited July 29, 2009). Even American Catholic priests increasingly reject the sexual ethic that Geach propounds with respect to premarital sex, homosexual sex, and contraception. See Andrew Greeley, The Catholic Revolution: New Wine, Old Wineskins, and the Second Vatican Council 124 (2004)

95 Amy L. Wax, Engines of Inequality: Class, Race, and Family Structure, 41 Fam. L. Q. 567, 599 (2007).

96 Wax, The Conservative's Dilemma, at 1079.

97 Maggie Gallagher, (How) Will Gay Marriage Weaken Marriage as a Social Institution: A Reply to Andrew Koppelman, 2 U. of St. Thomas L. J. 33, 47 (2004).

98 Gallagher writes that "[s]ame-sex marriage will affect marriage by changing our core legal understanding of what marriage is. Marriage 
We wouldn't have the institution of marriage without procreation. But what's wrong with using an institution for unanticipated purposes? The authors of the federal Constitution, many of whom owned slaves, did not intend the use of federal power to abolish slavery. The builders of the Parthenon did not intend that it be maintained as an attraction for tourists and scholars. Saddam Hussein did not intend that his presidential palaces be used to house a democratically elected government. When a novel use of an inherited institution is proposed, the question ought to be whether that use is a good one, not whether it is consistent with the institution's original purpose.

My real disagreement with Wax has to do with the importance of miracle, mystery, and authority. The old ethic did its job for a long time. But to say that children can't thrive without the old sexual morality because they need to be connected with their fathers is like saying that animals can't live on land because they need gills to breathe. I'm not persuaded that people have to be fooled into being good parents. I repeat what I said before: I have three kids, and I don't think I stick around because I'm mystified or confused. ${ }^{99}$

The basic Burkean point, that ancient rules probably have a rational basis or they wouldn't have survived so

will be a unisex relationship, unconnected to sex, babies or family structure." Maggie Gallagher, Maggie's Reply to Andrew Koppelman on Marriage and Same-Sex Marriage, Oct. 4, 2005, available at http://www.marriagedebate.com/mdblog/2005 10 o2 mdblog archive.htm. Here's a nice test of whether marriage, disconnected to reproduction, will have that consequence. Arizona and Wisconsin have statutes that allow first cousins to marry only if they can't procreate. (Ariz. Rev. Stat. 25-101(B); Wisc. Stat. Ann. 765.03.) How alarmed ought we to be about these laws? Do they install "a new definition of marriage, one disconnected from its historic meaning, purpose and function"? Id. Is this "going to make it much harder for parents and faith communities to promote the understanding that marriage is about generativity: connecting mothers and fathers to the children they make"? Id.

99 Koppelman, Decline and Fall, at 30. To this Maggie Gallagher responds: "This is a soundbite, not a serious thought. It amounts to a rejection of the idea that the social meanings encoded in law matter. The law interacts only by directly punishing or directly benefiting free and disparate individuals. The law is an administrator alone. Its ideas do not have any consequences." (How) Will Gay Marriage Weaken at 58. Hardly. I once wrote a whole book, Antidiscrimination Law and Social Equality (1996), arguing that the shaping of social meaning is a legitimate undertaking for the law. See also Andrew Koppelman, On the Moral Foundations of Legal Expressivism, 60 Maryland L. Rev. 777 (2001). What I doubt is that same-sex marriage will have the specific social meaning Gallagher claims it will: an invitation for men to desert their wives and children. I doubt that any father on the planet will interpret it that way. 
long, is sound. But conditions change. Compare the prohibition of usury. In the primitive agrarian societies of Biblical times, a loan was likely to be a response to unexpected disaster, and the ban on charging interest was a way of preventing people from exploiting others' misfortunes. As modern commercial conditions changed, and finance became an unavoidable prerequisite of business, casuists quickly figured out that conditions had changed and so the old rules had to be modified. ${ }^{100}$

There is a moral anchor amid this historical contingency: the idea that people have value, that their needs should be looked after, and that it's wrong to regard another person as merely a source of economic gain. With sex as with lending, people shouldn't stand toward one another in the relation of predator and prey. ${ }^{101}$

The old rules of sex are valuable because they cope with the problem of unintended pregnancy, which hasn't gone away. But the old rules turn out to have costs. Most obviously, people want to be happy, and the ban on divorce is a problem for that. ${ }^{102}$ The ban on contraception never made a lot of sense, absent condemnation of pleasure in sex. And, of course, the cost to gay people of the traditional sexual ethic was extremely high. So a more flexible set of rules have developed: premarital sex is fine as long as contraception is carefully used; there's a strong presumption against adultery (though some married couples have tolerated it, and some even testify that tolerating it has helped hold their marriages together). A

100 Albert R. Johnson \& Stephen Toulmin, The Abuse of Casuistry: A History of Moral Reasoning 181-94 (1988). The similarities between the usury and homosexuality taboos have been noted in John Corvino, Why Shouldn't Tommy and Jim Have Sex? A Defense of Homosexuality, in Same Sex: Debating the Ethics, Science, and Culture of Homosexuality 12-14 (Corvino ed. 1997), and John Boswell, Christianity, Social Tolerance, and Homosexuality: Gay People in Western Europe from the Beginning of the Christian Era to the Fourteenth Century 330-32 (1980).

101 The old Biblical anti-usury ethic continues to be relevant. There is now a large subsector of the credit card industry whose function is predation, pure and simple - worse than usury in Biblical times, because the lender then did not deliberately engineer the economic desperation from which he then profited. See Ronald J. Mann, Bankruptcy Reform and the "Sweat Box" of Credit Card Debt, 2007 Ill. L. Rev. 375.

102 Geach claims that the availability of divorce has made marriages unhappier. Marriage at 188-90. In fact, it uncertain whether marriages have become happier or unhappier, and whether any change that has occurred is the result of changing divorce laws or of other factors, such as the decline in many husbands' wages. See Paul R. Amato et al., Alone Together: How Marriage in America is Changing 32 (2007). 
central task of modern sexual ethics is to figure out what is living and what is dead in the old rules about sex, and where the lines are now to be drawn. ${ }^{103}$ The eminently responsible parental behavior of the people who have most firmly embraced the new ethic suggests that that ethic is less dangerous than Geach and Wax fear.

Geach observes that I have not attempted to offer "an account of sexual virtue in general."104 The emergence of the new middle class ethic suggests that there is no such thing as a single sexual virtue for all human beings. The ethic that demands premarital chastity, above all of women, evidently is not indispensable in all societies.

This is not the place to answer Geach's challenge, but I can say a few things about sexual virtue as I understand it. Begin with the noncontroversial, though perhaps trivial, premise that virtue is a disposition to choose well. Sexual virtue is a disposition to make good choices about sex. This has negative and positive implications. Begin with the negative.

Sex is, in characteristic ways, a frequent occasion for mistreatment of human beings: physical and emotional abuse, manipulation and deception, the reckless spread of disease, and the irresponsible begetting of children. Since one should not mistreat people, a fortiori one should not mistreat them in this sphere. The old and new sexual ethics converge here, though they disagree about the best strategy for avoiding such mistreatment.

There is also the question of the positive goal toward which choice should aspire. The fundamental disagreement between the old and new sexual ethics is here. I have already stated why I am not persuaded by the account of that telos offered by NNL and Geach. Can I offer anything better?

I agree that the goodness of sex at its best has to do with its character as a certain kind of interpersonal communion. "Conversation," Geach observes, "is delightful because it is good to share thoughts in this way, and a part of friendship (not just a means to friendship but a part of what is constitutive of it) and we take pleasure,

103 There are a lot of people working on this, of course. One of my favorites is the advice columnist Dan Savage, who delicately tries to work out an appropriate etiquette for group sex, bondage, fetishism, and other unusual tastes. The need to treat other people decently and with due consideration for their feelings is a dominant concern of his work, and his popularity suggests that in this he is not idiosyncratic. See, e.g., Dan Savage, Savage Love: Straight Answers From America's Most Popular Sex Columnist (1998).

${ }^{104}$ Lying, at 552. 
we delight in, what we find good."105 Sex at its best is something like conversation. It is not something you can do by yourself. It is essentially interaction with another person, an interaction in which you love and value me in my wholeness, as body and mind and infantile neediness, and I love and value you in the same way. When I am the object of lust, this sometimes means that I am appreciated in the full embodied particularity of my self, as I am not if you only love me for my mind. ${ }^{106}$ Sexual virtue is a disposition to pursue sex at its best.

It is only in this sense that Geach is correct that the sex act is, "like the act of telling, a kind of human act which is, as it were, there already for us to do, whose generic nature is not formed by the agent's thought."107 But she misapprehends the character of the goodness of the act in question, which is not essentially related to its procreative character. These goods are good without reference to reproduction. It radically misunderstands the point of nonreproductive sex to say that its purpose is merely pleasure.

The telos of sex that I have described has implications for the moral status of sex acts that fall short of this interpersonal ideal. Many people are unable to achieve the full goodness associated with sex at its best, often because of the simple bad luck of never meeting a suitable partner. When a given sexual act, one that involves no mistreatment of another person, is the best that is available for this person at this time, it is uncharitable to condemn it. Sex at its best demands generosity toward human neediness and imperfection. There is, then, something paradoxical and unvirtuous about condemning sex for being imperfect. ${ }^{108}$ The stigmatization of masturbation, for example, is senseless and destructive precisely because of its brutal attitude toward sexual neediness.

Finally, a word about pleasure. For the reasons just stated, many of the couplings that Geach condemns are aiming at something more than pleasurable sensations, fundamentally private and meaningless. But it would be

105 Id. at 542 .

106 Roger Scruton, Sexual Desire: A Moral Philosophy of the Erotic 68-83 (1986), is the best development of this idea that I know, though I share the reservations stated by Martha Nussbaum in her review, Sex in the Head, 33 N. Y. Rev. of Books 49-52 (Dec. 18, 1986).

${ }^{107}$ Geach, Lying, at 553.

108 See my Eros, Civilization, and Harry Clor, 31 N.Y.U. Rev. L. \& Soc. Change 855 (2007). 
strange if pleasure were never a legitimate reason for action. Would Geach deny that, in the intercourse of married heterosexual couples that she valorizes, one sometimes legitimately performs intentional actions for no reason other than these give one's partner physical pleasure?

The ex-gay movement as Trojan horse

There's a substantial problem about the people who are left out of Geach's picture. If her ethic's contribution to human flourishing is to be counted in its favor, then we should pay some attention to the ways in which it crushes the human spirit. There is a very large population of people who are primarily sexually attracted to people of the same sex. They comprise between two and ten percent of the population. ${ }^{109}$ What are they supposed to do?

The costs of the homosexuality taboo are well-known, but it is worth noting that those costs are being registered even within the heart of the religious right in America.

The October, 2007, issue of Christianity Today included a fascinating piece about the evolution of the "ex-gay" movement. ${ }^{110}$ The article inadvertently exposes a major fault line in the Christian Right's position on homosexuality.

The article, unsurprisingly given its venue, takes as unquestioned premises that homosexual desire and homosexual conduct are always evils to be avoided. It notes an important shift in the claims being made by the "ex-gay" movement, a primarily Christian movement that has been around for some decades now, promising to lead gay people away from homosexuality. In the early days of the movement, it claimed that a gay person could transform himor herself into a heterosexual through a pure act of will. Those claims have now disappeared. The article reports that "[e]arly hopes for instant healing have given way to belief that transformation occurs through a lifetime of discipleship."

109 The number varies depending on whether measurement focuses on selfidentification (in which case the percentage is low) or on behavior (in which case it is higher). Edward O. Laumann, John H. Gagnon, Robert T. Michael, and Stuart Michaels, The Social Organization of Sexuality: Sexual Practices in the United States 292-301 (1994); Richard Posner, Sex and Reason 294-95 (1992).

${ }_{110}$ Tim Stafford, An Older, Wiser Ex-Gay Movement, Christianity Today, Oct. 2007. 
Alan Chambers, president of Exodus International, the largest of the ex-gay groups,

is frank that change does not eradicate temptation. He wonders if change is ever 100 percent complete in this life. 'One thing we can expect as Christians is a life of denial,' he says. 'I don't think we're afraid to tell people that they may have a lifetime of struggle. Freedom isn't the absence of struggle, but the life of struggle with joy in the process.'

The ex-gay movement seeks to integrate the reality of same-sex attraction into a life of discipleship. In that lifelong journey, they expect many changes, including changes of feeling and attraction. But they emphasize that each person's experience is different, and that instant transformation is extremely rare.

Not surprisingly then, ex-gay ministries appeal almost exclusively to Christians. Most participants come from evangelical backgrounds and can't resolve their Christian faith with a gay identity. An accompanying article ${ }^{111}$ describes a recent study of "reparative therapy" (therapy that seeks to transform sexual orientation). The study struggles to cast that therapy in the best possible light. But among those who were deemed to have successfully converted to heterosexual, most

did not report themselves to be without experience of homosexual arousal, and did not report heterosexual orientation to be unequivocal and uncomplicated. Sexual orientation for the individuals in this study (and indeed for most of us) may be considerably more complicated than commonly conceived, involving a complex interplay of what we are instinctively attracted to, what we can be attracted to with proper attention and focus, what we choose to be attracted to based on how we structure our interpersonal environments, our emotional attachments, our broader psychological functioning, (of course) our religious and moral beliefs and values, and many more factors. We believe the individuals who presented themselves as heterosexual success stories at Time 3 are

111 Tim Stafford, The Best Research Yet, Christianity Today, Oct. 2007. 
heterosexual in some meaningful but complicated sense of the term.

The abandonment of the claim that sexual orientation can easily be changed is very big news. Poll data reveal that those who think homosexuality is innate are overwhelmingly likely to support gay rights, while those who think homosexuality is a choice are likely to be opposed. "Of those who consider it a choice," a New York Times poll reported in 1993, "only 18 percent rated it as acceptable, compared with 57 percent of those who regard it as something gay men and lesbians cannot change."112

There's nothing illogical about thinking that homosexuality is innate and nonetheless opposing gay rights. One can regard it as an unfortunate fact of life that some people are permanently denied sexual happiness. The Christianity Today article ends on that note: "Our attractions, always disordered to some extent, must be submitted to Christ, who alone can redeem us. For those who feel strong same-sex attractions, that task is especially difficult. But it is the same basic struggle every Christian must face."

But that story is a hard sell. Americans like happy endings. They like to think that if homosexual sex is forbidden, then another avenue to sexual fulfillment is easily available to gay people. That's why the leadership of the Christian Right has tended to be quiet about the ambiguities in the experience of those in the ex-gay movement. As recent studies of the ex-gay movement have shown, this has produced considerable tensions. ${ }^{113}$ One committed member of the movement denounced the hypocrisy of his fellow Christians:

Most of them can't handle the truth. If you're in the church and you're a drug addict, murderer, whatever, guys will come up to you and slap you on the ass.

112 Jeffrey Schmalz, Poll Finds an Even Split on Homosexuality's Cause, N.Y. Times, Mar. 5, 1993. The same correlation has been found in dozens of surveys over several decades: "regarding a homosexual orientation as freely chosen has consistently been associated with more negative attitudes toward gay people and opposition to gay rights." Gregory M. Herek, Gender Gaps in Public Opinion About Lesbians and Gay Men, 66 Pub. Opn. Q. 40, 46 (2002).

113 Tanya Erzen, Straight to Jesus: Sexual and Christian Conversions in the Ex-Gay Movement (2006); Michelle Wolkomir, Be Not Deceived: The Sacred and Sexual Struggles of Gay and Ex-Gay Christian Men (2006). 
You're one of the guys. But if you state you struggle with homosexuality, you get the whole pew to yourself. ${ }^{114}$

The appearance of the Christianity Today article is a significant event, because it shows that mainstream conservative Christianity is now willing to admit these uncomfortable facts. This, however, is a decidedly unstable cultural formation. It is also liable to slippage, as when Michael Bussee, one of the founders of Exodus International, fell in love with one of the members. They left the group together and never came back. ${ }^{115}$

The ex-gay movement is, wittingly or not, a progressive force in American politics. It demands that the immutability claim be taken seriously, and its members are not easily dismissed by the religious right, because they agree with the religious right about nearly everything else. They have a credibility and a competence in the pertinent theological claims that no one else can possibly match. They are able to speak to their own cultural group, in the same way that sophisticated Islamic feminist theologians can speak to theirs.

of course, it's possible to say that, even though Geach's sexual ethic will not make people happy, even though it will doom them to a life of struggle and frustration, they should accept this, because that's the right thing to do.

But this sits uneasily beside her invocation of the happy lives of those who follow the path she prescribes. Both "This is the Path to Happiness" and "Tough Luck, Happiness Isn't for You" are coherent positions. ${ }^{116}$ But it's hard to make them cohere with each other.

114 Erzen, Straight to Jesus, at 66 .

115 Wolkomir, Be Not Deceived, at 28-30.

116 Lee and George, who occupy the second position, have no trouble dismissing a priori the testimony of gay people about the value of their sexual acts. Since their philosophical position establishes that such acts are worthless and harmful, any experience to the contrary, even voluminous experience, can be dismissed as illusory. What MaleFemale Complementarity Makes Possible at 653-55.

Happy gay people are more of a problem for Geach, who writes that "by sins against chastity and the marriage good we damage ourselves inside," and notes that the art of gay artist Francis Bacon "suggests that he at least had a vision of this damage." Geach, Lying, at 533. Bacon specialized in nightmarishly twisted portraits. "A man who knows that he is denying the value of humanity by what he does will be 
There remains a difficulty about the line that Geach draws to separate licit from illicit sex. The insistence on a link between sex and reproduction raises a familiar objection: why is it morally permissible for infertile heterosexual couples to copulate? ${ }^{117}$

Like the new natural law theorists, Geach focuses on the capacity of the heterosexual couple to engage in acts of the reproductive kind. I have already reviewed the objections to this claim. Geach, unlike the new natural lawyers, does not claim that a copulating married couple becomes a single organism. Rather she responds to these difficulties in an original way. She is especially provoked by the following passage from my work, in which I elaborated on the gun example, discussed earlier.

Contingencies of deception and fright aside, all objects that are not loaded guns are morally equivalent in this context: it is not more wrong, and certainly not closer to homicide, to point a gun known to be unloaded at someone and pull the trigger than it is to point one's finger and say, "bang!" And if the two acts have the same moral character in this context, why is the same not equally true of, on the one hand, vaginal intercourse between a heterosexual couple who know they cannot reproduce, and on the other, anal or oral sex between any couple? Just as, in the case of the gun, neither act is more homicidal than the other, so in the sexual cases, neither act is more reproductive than the other. ${ }^{118}$

Geach responds: "If gun-users in America make no such distinction, this must cause a lot of nasty accidents. Good gun practice treats the actions as utterly different:

distorted like a Francis Bacon picture, which illustrates the effects of sodomy on the soul." Id. at 554 .

117 The infertile couple is also a problem for Gallagher, who writes in (How) Will Gay Marriage Weaken at 45 n.34 that elderly infertile couples "do not contradict in any intelligible, visible way, the basic purposes of marriage as a childrearing institution." When the 70 year old couple marries, does anyone think that they might have children? She explains that "we know for a fact that including these kinds of opposite-sex couples doesn't damage the meaning of marriage as a childrearing institution," id., because they've always been included in it. But for reasons we have already considered, same-sex marriage doesn't damage the meaning of marriage as a childrearing institution for the new sexual ethic.

118 Koppelman, The Gay Rights Question, at 88 . 
one has to make a strict rule against ever pointing guns at people unless one seriously means to shoot someone, and if one killed someone by shooting him accidentally in this way one would be to blame for his death."119 If one does not make good gun practice a habit, one damages oneself by making oneself into the kind of gun-user who might kill someone. This, Geach concedes, is not an absolute moral rule; in narrowly defined circumstances, a departure from good gun practice might be warranted, because it would not necessarily damage the self in this way. "By contrast, a sexual act which fails to be of generative kind directly attacks the fabric and constitution of our nature, since our sexuality and the significance of the marriage act are part of that fabric and constitution."120

The point about good gun practice doesn't add much to the argument, since it rests on the contingency of human limitations. If we had X-ray vision and could see instantly whether a gun was loaded, good gun practice would be different than it is. If the point is that we need to habitually follow traditional sexual ethics because such rules provide a socially useful framework, even if there is no distinctive reason in any particular case to follow them, this comes dangerously close to Wax's position. The deeper question is one of coherence: does it make sense to say that the significance of reproduction adheres to an act that is known to be incapable of reproduction? Geach's answer is the same as the NNL theorists: "Generation, when it takes place normally, involves a joint human act, which as a kind of human act is not defined as involving, for instance, the expedition of viable sperm, since the viability of sperm is a piece of recondite information."121 But in given circumstances, that information may not be recondite at all. Sometimes we all have the functional equivalent of X-ray vision. A man may know perfectly well that he is infertile, or more commonly (in a case such as post-menopausal sex) that his wife is. Why is their coitus an act of the reproductive type, when they know for certain that it cannot possibly produce a pregnancy?

Geach observes that my objection presupposes that a given moral character "cannot belong to an act as being of a kind to produce a certain effect, unless it is in the

119 Geach, Lying, at 551 .

120 Id.

121 Id. at 550 . 
circumstances liable to produce that effect."122 But Geach denies this:

Thus, I suppose, [Koppelman] would say that it could make no difference to the moral character of one's action whether one had or had not provided information, if, as it happened, there was no way that one would be believed when one made some assertion of informative kind. But it could make a great difference to whether one had done one's job, or made one's protest, or warned one's enemies of the disaster about to overtake them. To provide information is to make an assertion of the kind called 'telling', which is distinguished from other kinds of assertion by its being an act of a kind to produce in the hearer belief of the one making the assertion. The fact that one will not be believed, however, does not mean that one is not performing the act of telling, and whether or not one has actually told someone something can make a great difference to the character of one's action, even if one is not trying to make him believe one. ${ }^{123}$ Much depends on what is meant by "the fact that one will not be believed." Suppose that I'm trying to warn my enemy that the bridge he's determined to cross is going to collapse and plunge him to his death. I can be fairly sure, given his characteristic stubbornness and stupidity, that he's going to disregard my warning. I'm obligated to warn him nonetheless.

But when I do that, I have to use means that I think have some chance of getting through to him, and I have to reasonably hope that this time I will get through to him. Stubborn, stupid people sometimes unexpectedly reform. (We are born stubborn and stupid.) If it is absolutely impossible for him to be informed, then my telling him is as pointless as if I told him the truth in a foreign language which he does not understand. One isn't "performing an act of informative kind" if "one makes one's statement out of earshot."124

Geach thinks that the analogous case is that "one is not performing an act of reproductive kind unless there is

122 Id. at 552. Similarly, Lee and George observe that "the key assumption in Koppelman's argument" is that "No act in which the agents (or parts of the agents) lack the full internal resources (in a suitable environment, under certain circumstances) in producing $\mathrm{X}$ can be internally oriented toward X." Body-Self Dualism, at 202. I am indeed making this assumption, which I defend infra text accompanying notes $31-32$.

123 Geach, Lying, at 552 . 124 Id. 
reproductive complementarity."125 But why is my act of the reproductive kind if I am ejaculating into an infertile vagina (but not of the reproductive kind if I ejaculate anywhere else)? Why isn't this just like a truthful statement made out of earshot? As our discussion of Lee and George, above, showed, a hopeless struggle is admirable only if there is some rational vestige of hope present. Otherwise it's just silly. The surgeon can't perform a healing-type act upon a corpse. Come to think of it, it doesn't make much sense to make a truthful statement to a corpse, either.

Conclusion

A common refrain among opponents of same-sex marriage - all the writers I have critiqued here partake of it - is the importance of defending "the family." They feel that the institution of the family, as they conceive it, will be undermined if same-sex marriages are recognized. This is a peculiar kind of argument, and it traps them in a paradox that has a remarkable historical precedent.

In the Civil War, the Southerners frequently declared that they were fighting for liberty and self-government. The title of James McPherson's history of the Civil War, Battle Cry of Freedom, capitalizes on the fact that, as McPherson writes, "[b]oth sides . . professed to be fighting for freedom."126 Jefferson Davis declared in 1863 that the South was "forced to take up arms to vindicate the political rights, the freedom, equality, and state sovereignty which were the heritage purchased by the blood of our revolutionary sires."127 But the freedom that Davis was fighting for depended, of course, on the enslavement of others. The southern commissioners to Britain reported home that "the public mind here is entirely opposed to the Government of the Confederate States of America on the question of slavery. . . . The sincerity and universality of this feeling embarrass the government in dealing with the question of our recognition."128

Opponents of same-sex marriage today face a similar embarrassment. They are eager to protect their distinctive conception of family. But that conception depends on marginalizing the families of others and denying them legal

125 Id.

126 James M. McPherson, Battle Cry of Freedom: The Civil War Era vii (1988) .

$127 \mathrm{Id}$.

128 Id. at 311 . 
recognition. In the long run, the invocation of "family" as a reason to beat up on gay people will seem as weird as the invocation of "freedom" did as a defense of the Confederacy. 